\title{
The Correlation Between Fine Needle Aspiration Cytology and Histopathology of Head and Neck Lesions in Kathmandu University Hospital
}

\author{
Rajbhandari M, ${ }^{1}$ Dhakal $P,{ }^{1}$ Shrestha $S,{ }^{1}$ Sharma $S,{ }^{1}$ Shrestha $S,{ }^{1}$ Pokharel $M,{ }^{2}$ Shrestha I, \\ Shrestha B, ${ }^{2}$ Makaju ${ }^{1}$
}

${ }^{1}$ Department of Pathology

${ }^{2}$ Department of ENT

Dhulikhel Hospital- Kathmandu University Hospital Kathmandu University School of medical Science

Dhulikhel, Kavre, Nepal

\section{Corresponding Author}

Merina Rajbhandari

Department of Pathology

Dhulikhel Hospital- Kathmandu University Hospital Kathmandu University School of medical Science

Dhulikhel, Kavre, Nepal

E-mail: rajbhandarimerina@hotmail.com

Citation

Rajbhandari M, Dhakal P, Shrestha S, Sharma S, Shrestha S, Pokharel M et.al. The Correlation Between Fine Needle Aspiration Cytology and Histopathology of Head and Neck Lesions in Kathmandu University Hospital. Kathmandu Univ Med J 2013;44(4):296299.

\section{ABSTRACT \\ Background}

Fine needle aspiration cytology (FNAC) with it's minimally invasiveness has been a well accepted procedure in the initial diagnosis of various swellings. With time and experience high sensitivity and specificity of FNAC over conventional open biopsy has lead to the wide acceptance of this procedure.

\section{Objective}

To evaluate the utility of aspiration cytology as a first-line diagnostic tool in palpable head and neck masses and correlate with histologic results for evaluating diagnostic accuracy.

\section{Methods}

A hospital based prospective, comparative study was conducted among patients with various swellings at Head and Neck regions in the Department of Pathology, Dhulikhel Hospital between July 2011 to June 2012. FNAC were done from the palpable masses of head and neck regions and were compared with biopsy findings of the same lesions. Data entry and analysis performed using SPSS version 16. The sensitivity, specificity and accuracy rates were calculated.

\section{Results}

A total 64 patients were subjected to both FNAC and histopathological examination (HPE). Total 39 (61 \%) were females and 25 (39\%) were males with M: F ratio of 1:1.6. The age group ranged from 9 to 80 years. Twenty five percent of patients were in the age group below 20 years. The highest number of cases included lymph nodes 29 (45\%) followed by thyroid $24(37.5 \%)$, salivary glands $10(16 \%)$ and 1 case (1.6\%) was a soft tissue swelling over the occipital region. Highest sensitivity, specificity and accuracy rate for diagnosis by FNAC were observed in thyroid. The overall sensitivity and specificity of FNAC were $86 \%$ and $97 \%$ respectively in determining the various pathologies. The overall accuracy of FNAC in present study was $87.4 \%$.

\section{Conclusion}

FNAC is a minimally invasive first line investigation with a high sensitivity and specificity for the diagnosis of various head and neck lesions

\section{KEY WORDS}

FNAC, lymph nodes, salivary Glands, thyroid 


\section{INTRODUCTION}

Fine needle aspiration cytology with its minimally invasive procedure has been helpful in the diagnosis of various swellings. ${ }^{1}$ Since its introduction in 1930 by Martin, the procedure has become increasingly popular in the evaluation of various palpable lumps. ${ }^{2}$

FNAC is of relevance as it is safe, inexpensive procedure with a quick result and an excellent patient compliance. ${ }^{3}$ The head and neck region encompasses a wide range of lesions especially of thyroid, lymph nodes and salivary glands with a variety of differential diagnosis ranging from inflammatory to neoplastic. They account for almost one half of all body sites aspirated. To make an accurate and effective surgical intervention, it is essential to make a preoperative assessment of the nature of these lesions. ${ }^{4}$

The primary objective of the study was to assess the spectrum of head and neck masses and to determine the accuracy of FNAC in detection of various lesions in Kathmandu University Hospital.

\section{METHOD}

The present study included 64 cases of head and neck swellings who had undergone preoperative FNAC and subsequently histopathological examination were included in the study. The ethical approval was taken from Ethical Review Committee(IRC).

FNAC was performed by 22-23 gauged needles with syringe. The specimen was expelled on one or two glass slides according to the amount of material and smeared, wet fixed or air dried followed by staining with Giemsa and Papanicolaou stain (PAP) similarly, biopsies obtained from these patients were fixed in $10 \%$ formalin. Sections were taken from different parts of the specimen and processed. The sections so obtained were stained with hematoxylin and eosin (HE) stains. This was followed by cytologicalhistopathological comparison. Sensitivity,specificity and diagnostic accuracy of FNAC was calculated. Patients of both sexes and all age groups were included in the study.

\section{RESULT}

Age of the patients ranged from 9-80 years with a median age of 42 years. Maximum numbers of lesions were observed in the age group below 20 years including the malignant lesions. Overall there was a female predominance with a $M: F$ ratio of 1:1.6. The maximum difference was in the thyroid lesions with a M:F ratio of 1:7.5 followed by salivary glands 1:1.5. However, in Lymph nodes there was a male dominance with a ratio of 1.6:1.

A total of 316 FNACs of various thyroid and non thyroid lesions of head and neck were obtained in a period of 12 months between July 2011 to June 2012. In 64 patients, HPE was performed which comprised 29 (45\%) cases of lymph nodes (anterior cervical, posterior cervical submental, submandibular and supraclavicular ) 24 (37.5\%) cases of thyroid, $10(16 \%)$ cases of salivary gland ( 5 parotid, 4 submandibular and 1 minor salivary glands) and miscellaneous included 1 (1.5\%) case of soft tissue swelling over the occipital region. The FNAC and HPE comparison were made among them(Table 1 ).

Table 1. Cyto-Histological Correlation of Lymph Nodes.

\begin{tabular}{|c|c|c|}
\hline FNAC Reports (n) & $\begin{array}{l}\text { Histopathological } \\
\text { Report REPORTS (n) }\end{array}$ & Accuracy Rate \\
\hline Reactive $(n=18)$ & $\begin{array}{l}\text { Reactive }(n=14) \\
\text { Non Hodgkins Lym- } \\
\text { phoma }(n=4)\end{array}$ & $\begin{array}{l}77.8 \% \text { ( } 4 \text { False } \\
\text { negative for malig- } \\
\text { nancy) }\end{array}$ \\
\hline Tuberculosis $(n=5)$ & Tuberculosis $(n=5)$ & $100 \%$ \\
\hline $\begin{array}{l}\text { Metastatic Adenocarci- } \\
\text { noma }(n=2)\end{array}$ & $\begin{array}{l}\text { Metastatic } \\
\text { Adenocarcinoma }(n=2)\end{array}$ & $100 \%$ \\
\hline $\begin{array}{l}\text { Hodgkin } \\
\text { Lymphoma }(n=1)\end{array}$ & $\begin{array}{l}\text { Hodgkin } \\
\text { Lymphoma }(n=1)\end{array}$ & $100 \%$ \\
\hline $\begin{array}{l}\text { Non Hodgkin } \\
\text { Lymphoma }(n=3)\end{array}$ & $\begin{array}{l}\text { NonHodgkin } \\
\text { Lymphoma( } n=2) \\
\text { Reactive }(n=1)\end{array}$ & $\begin{array}{l}66 \% \text { ( } 1 \text { False posi- } \\
\text { tive for malignancy) }\end{array}$ \\
\hline
\end{tabular}

Among lymph nodes, the final diagnosis were reactive lymphadenitis(15), Tuberculosis(5), metastatic adenocarcinoma(2), Hodgkin Lymphoma(1) and Non Hodgkins Lymphoma (6) with a sensitivity, specificity and accuracy rate of $82.7 \%, 96 \%$ and $88.76 \%$ respectively (Table2).

Table 2 . Cyto-Histological Correlation of Salivary Glands.

\begin{tabular}{lll}
\multicolumn{1}{c|}{ FNAC Reports $(\mathrm{n})$} & $\begin{array}{c}\text { Histopathological Report } \\
\text { REPORTS }(\mathrm{n})\end{array}$ & $\begin{array}{c}\text { Accuracy } \\
\text { Rate }\end{array}$ \\
\hline $\begin{array}{l}\text { Chronic sialadenitis }(\mathrm{n}=4) \\
\text { Pleomorphic } \\
\text { adenoma }(\mathrm{n}=3)\end{array}$ & $\begin{array}{l}\text { Chronic sialadenitis }(\mathrm{n}=4) \\
\text { Pleomorphic }\end{array}$ & $100 \%$ \\
\hline Benign cystic lesion $(\mathrm{n}=2)$ & Warthin's Tumor $(\mathrm{n}=2)$ & $0 \%$ \\
\hline $\begin{array}{l}\text { Mucoepidermoid } \\
\text { carcinoma }(n=1)\end{array}$ & $\begin{array}{l}\text { Mucoepidermoid } \\
\text { carcinoma }(n=1)\end{array}$ & $100 \%$ \\
\hline
\end{tabular}

Similarly, chronic sialdenitis (4) were the commonest lesion in salivary glands followed by pleomorphic adenoma (3), warthin's tumor (2) and mucoepidermoid carcinoma (1). For the diagnosis of salivary gland lesions the FNAC and HPE was concordant with a sensitivity, specificity and accuracy rate of $80 \%, 100 \%$ and $75 \%$. Chronic inflammation of salivary glands are often associated with ductal obstruction with stones. In our study, in all four salivary glands (1 parotid and 3 submandibular) operated for chronic sialadenitis showed presence of stones in the gland during sectioning of the gland for histopathology indicating clinically towards the excision of glands.(Table 3)

Following FNAC and HPE the final diagnosis of thyroid swellings were nodular colloid goitre (4), colloid goitre with cystic changes (1), hashimoto thyroiditis (2), papillary carcinoma (4) and follicular Neoplasm (11) with overall sensitivity, specificity and acccuracy rate of $96 \%, 100 \%$ and $92.85 \%$ respectively. All the patients were subjected 
Table 3. Cyto-Histological Correlation of Thyroid.

\begin{tabular}{|c|c|c|}
\hline FNAC Reports ( $n$ ) & $\begin{array}{l}\text { Histopathological Report } \\
\text { REPORTS (n) }\end{array}$ & $\begin{array}{l}\text { Accuracy } \\
\text { Rate }\end{array}$ \\
\hline Colloid Goitre $(n=5)$ & Colloid Goitre(n=5) & $100 \%$ \\
\hline Benign Cystic Lesions( $n=2)$ & $\begin{array}{l}\text { Colloid Goitre with cystic } \\
\text { changes }(n=1) \\
\text { Papillary carcinoma }(n=1)\end{array}$ & $\begin{array}{l}50 \% \text { (1 False } \\
\text { negative for } \\
\text { malignancy) }\end{array}$ \\
\hline Papillary carcinoma $(n=3)$ & Papillary carcinoma )n=3) & $100 \%$ \\
\hline Follicular Neoplasm $(n=11)$ & $\begin{array}{l}\text { Follicular Adenoma }(n=8) \\
\text { Follicular carcinoma }(n=3)\end{array}$ & $100 \%$ \\
\hline $\begin{array}{l}\text { Hashimoto } \\
\text { Thyroiditis }(n=2)\end{array}$ & $\begin{array}{l}\text { Hashimoto } \\
\text { Thyroiditis }(n=2)\end{array}$ & $100 \%$ \\
\hline $\begin{array}{l}\text { Lymphocytic } \\
\text { Thyroiditis }(n=1)\end{array}$ & $\begin{array}{l}\text { Lymphocytic } \\
\text { Thyroiditis }(n=1)\end{array}$ & $100 \%$ \\
\hline
\end{tabular}

to Thyroid function test and in 1 case with colloid goitre presented with hyperthyroidism, hence, the final report was dispatched as toxic nodular goitre. Though Hashimoto's thyroiditis and lymphocytic thyroiditis are not the indications for the removal of glands, patients had clinical features like rapidly enlarging mass with compressive features, persistent pain and in one case thyromegaly unresponsive to suppressive therapy which could have resulted in their removal.(Table 4 and 5)

Table 4. Cyto-Histological Correlation of Soft Tissue Swelling.

\begin{tabular}{|c|c|c|}
\hline FNAC Reports (n) & $\begin{array}{l}\text { Histopathological Report } \\
\text { REPORTS (n) }\end{array}$ & $\begin{array}{l}\text { Accuracy } \\
\text { Rate }\end{array}$ \\
\hline Lipoma $(n=1)$ & Lipoma(n=1) & $100 \%$ \\
\hline
\end{tabular}

Table 5. Sensitivity, Specificity and Diagnostic Accuracy of FNAC in Diagnosis of Head and Neck Lesions in the Study.

\begin{tabular}{|lllll|}
\hline $\begin{array}{c}\text { Organ of } \\
\text { Origin }\end{array}$ & FNAC/HPE & Sensitively & Specificity & $\begin{array}{c}\text { Accuracy } \\
\text { Rate }\end{array}$ \\
\hline Thyroid & $23 / 24$ & $96 \%$ & $100 \%$ & $92.85 \%$ \\
\hline Lymph Nodes & $24 / 29$ & $82.7 \%$ & $96 \%$ & $88.76 \%$ \\
\hline $\begin{array}{l}\text { Salivary } \\
\text { Glands }\end{array}$ & $8 / 10$ & $80 \%$ & $100 \%$ & $75 \%$ \\
\hline Miscellaneous & $1 / 1$ & $100 \%$ & $100 \%$ & $100 \%$ \\
\hline Total & $55 / 64$ & $86 \%$ & $99 \%$ & $87.44 \%$ \\
\hline
\end{tabular}

\section{DISCUSSION}

Head and neck masses are the common clinical conditions encountered. It is important to assess the conditions properly for the right management protocol as the differential diagnosis of head and neck swellings cover a broad spectrum of diseases.

In our study, efficacy of FNAC in the diagnosis of various thyroidal and non-thyroidal lesions of the head and neck were obtained. Overall sensitivity,specificity and diagnostic accuracy rate of $86 \%, 99 \%$ and $88.74 \%$ were achieved. This is comparable to the various other studies reported. (Table $6)^{5-8}$

During the FNAC procedure the aspirate was satisfactory in $92 \%$ and unsatisfactory in $8 \%$ of cases. The unsatisfactory
Table 6. Comparison of the Present Study with Other Studies.

\begin{tabular}{|llllll|}
\hline & $\begin{array}{l}\text { Present } \\
\text { Study }\end{array}$ & $\begin{array}{l}\text { Tilak } \\
\text { et.al }\end{array}$ & $\begin{array}{l}\text { Chauhan } \\
\text { et.al }^{6}\end{array}$ & $\begin{array}{l}\text { Tadon } \\
\text { et.al }^{7}\end{array}$ & $\begin{array}{l}\text { Mobley } \\
\text { et.al }^{8}\end{array}$ \\
\hline $\begin{array}{l}\text { Sensitivity } \\
86 \%\end{array}$ & $90.9 \%$ & $93.1 \%$ & $89.6 \%$ & $96.6 \%$ \\
\hline $\begin{array}{l}\text { Specificity } \\
\text { Accuracy }\end{array}$ & $99 \%$ & $93.2 \%$ & $100 \%$ & $96.5 \%$ & $97.7 \%$ \\
rate & $87.4 \%$ & $92.7 \%$ & $98.4 \%$ & $93 \%$ & $94.4 \%$ \\
\hline
\end{tabular}

aspirates were mainly from the swellings smaller than $1 \mathrm{cms}$ in size and from thyroid due to hemorrhagic aspirate.

In the present study, the highest degree of sensitivity (96\%) in diagnosing the thyroid gland pathologies document the utility of FNAC as a first line investigation in the management of such swellings. In different literatures, overall sensitivity of thyroid swellings range from $55 \%$ to $97 \% .{ }^{9,10}$ Two cases were diagnosed as thyroid cyst in FNAC on the basis of scant cellularity with presence of foamy macrophages, few follicular cells and colloid. Out of them, 1 was colloid goitre with cystic changes and another case as papillary carcinoma of thyroid in HPE. Absence of actual characters of papillary carcinoma such as papillary fragments, intranuclear inclusions, nuclear grooves and overlapping of nuclei have been attributed to the cytological confusion. ${ }^{11}$ Thus, in our study the accuracy rate in diagnosis of cystic lesions of thyroid was $50 \%$. It is documented that $20 \%$ of follicular neoplasm and $25 \%$ of papillary carcinoma have cystic changes. ${ }^{12}$ The possible solution to this can be multiple aspirations from the hypercellular areas. In a study by Ergete found carcinoma in cystic lesions in two persent of cases whereas no malignancy was in the cystic lesions by Sohail Raza. ${ }^{13,14}$

Maximum numbers of error were in the diagnosis of lymph node pathology. There were 4 false negative and 1 false positive reporting in FNAC of lymph nodes. Four lymph nodes diagnosed as reactive lymphadenitis by FNAC were later diagnosed as Non Hodgkin Lymphoma by histology. Different studies have shown the importance of the quality of cytological preparation besides the representativeness of the aspirate especially in the diagnosis of reactive lymphadenitis and in the diagnosis and classification of Lymphomas. ${ }^{5,15}$ Similarly, misinterpretation may be due to mixed population of lymphoid tissues and tingible body macrophages. Thus, we conclude the presence of macrophages suggest reactive hyperplasia but not always rule out lymphomas. Among one false positive was a case of lymphoma suggested by FNAC which was diagnosed as reactive lymphadenitis by histology. Germinal centers may be very large in some cases of reactive hyperplasia. If aspirates are obtained from such a large germinal centre, the increased number of large cells and increased mitosis may suggest it of malignancy.

Similar pattern of misinterpretation was also seen in reporting the cystic lesions of the salivary gland due to low diagnostic yield in aspiration. Overall sensitivity and specificity in FNAC of salivary glands in our study is concordant with that of Costa et al. ${ }^{16}$ The lesions categorized 
as benign cystic were reported as Warthin's tumor in HPE. Vaidya et al and Postema et al encountered the similar diagnostic dilemma and concluded the cytological diagnosis of cysts should be performed with caution. ${ }^{17,18}$

\section{ACKNOWLEDGEMENT}

I would like to thank Mr. Kishor Khanal for his help towards statistical analysis.

\section{REFERENCES}

1. KC S, Karki R, Rayamajhi P, Rai K, Piya E. Role of FNAC in the diagnosis of thyroid malignancy and its comparison with histopathology. Nep J of ENT head and neck surgery. 2012;3(1): 9-10.

2. Martin H, Ellis EB. Biopsy of needle puncture and aspiration. Ann Surg 1930;92:169-81.

3. Jasani JH, Vaishnani HV, Vekaria PN, Patel D, Shah Y. Retrospective study of fine needle aspiration cytology of head and neck lesions in tertiary care hospital. IJBAR. 2013;4:253-6.

4. Parikh UR, Goswami HM, Shah AM, Mehta NP, Gonsai RN. Fine needle aspiration cytology (FNAC) study of thyroid lesions-study of 240 cases. GMJ. 2012;67(2): 25-8.

5. Tilak $V$, Dhaded AV, Jain R. Fine needle aspiration cytology of head and neck masses. Indian J Pathol Microbiol. 2002;45(1): 23-9.

6. Chauhan S, Darad D, Dholakia A. Fine needle aspiration cytology of needle lesion-an experience at Tertiary care Hospital in Central Gujarat. NJMR. 2012;2: 255-9.

7. Tandon S, Shahab R, Benton JI,Ghush SK, Sheard J, Jones TM. Fine needle aspiration cytology in a regional head and neck cancer center : comparison with systemic review and meta-analysis. Head Neck 2008;30(9):1246-52.

8. Mobley DL, Wakely PE, Frable MAS. Fine needle aspiration biopsy: application to pediatric Head and Neck masses. Laryngoscope 1991;101: 469-72.

9. Naggada $H A$, Musa $A B$, Gali BM, Khalil MI. Fine needle aspiration cytology of thyroid nodules-A Nigerian Tertiary hospital experience. The Internet Journal of pathology. 2006; 5:1.

\section{CONCLUSIONS}

FNAC is recommended as a safe and reliable technique in diagnosis of thyroid and non-thyroidal head and neck lesions. It is a quick,convenient procedure and should be considered as a first line investigation in evaluation of the lesions of head and neck. Despite of high sensitivity there are certain pitfalls due to the misleading diagnostic yields and the diagnosis of reactive lesions in lymph nodes and various cystic lesions of head and neck have to be done only on the basis of adequate cellularity and inconjuction with the clinical history of the patient.
10. Handa U, Garg S, Mohan H, Nagarkar N. Role of fine needle aspiration cytology in diagnosis and management of thyroid lesions, a study of 434 patients. Journal of Cytology. 2008;25(1): 13-7.

11. Baloch ZW, Livolsi VA. Cytologic and architectural mimics of papillary thyroid carcinoma. Am J Pathol. 2006;125:135-44.

12. Orell SR,Sterrett GF, Whitaker D. Fine needle aspiration cytology. 4th Edn.London: Churchill-Livingstone,Elsevier ;2005.

13. Ergete W,Abebe D. Discordance rate between thyroid FNAC and histopathology diagnosis. Ethiopian J Health Dev. 2002;16: 227-9.

14. Raza S,Raza $H$,zahid Z. FNAC in management of solitary thyroid nodule. FNAC in management of solitary thyroid nodule. Professional Med J. 2006;13:596-9.

15. Hirachand S, Lakhey M, Akhter J, Thapa B. Evaluation of fine needle aspiration cytology of lymph nodes in Kathmandu Medical College, Teaching hospital. KUMJ. 2009;7:139-42.

16. Costa A, Castro P, Martin-Granizo R, Monje f, marron C, Amigp A. FNAB lesions of salivary glands. Br J Oral maxillofac Surg. 2000;38(5): 539-42.

17. Vaidya S, Sinha A, Narayan S, Adhikari S, KC S. A comparative study of fine needle aspiration cytology and histopathology in salivary gland lesions. JPN. 2011;1:108-13.

18. Postema RJ, Van MLF, Van den Brekel MWM, Balm AJM, Peterse JL. Accuracy of fine needle aspiration cytology of salivary gland lesions in Netherlands cancer Institute. Head Neck. 2004;26:418-24. 